\title{
Characterization of patients with massive hypertrophic cardiomyopathy using contrast- enhanced magnetic resonance imaging: does contrast provide additional information?
}

\author{
Raymond H Chan ${ }^{1 *}$, Susie Hong ${ }^{1}$, Tammy S Haas ${ }^{3}$, Kristin Feeney ${ }^{1}$, John Lesser ${ }^{3}$, Michael C Gibson ${ }^{1}$, \\ Warren J Manning ${ }^{1}$, Barry J Maron ${ }^{3}$, Martin Maron², Evan Appelbaum ${ }^{1}$
}

From 15th Annual SCMR Scientific Sessions

Orlando, FL, USA. 2-5 February 2012

\section{Background}

Hypertrophic cardiomyopathy (HCM) patients with massive left ventricular hypertrophy (LVH) (hereby defined as maximal LV wall thickness $>30 \mathrm{~mm}$ ) are known to have lower rates of survival. Recently, contrast-enhanced cardiac magnetic resonance (CMR) with late gadolinium enhancement (LGE) has emerged as a potential novel marker of increased cardiovascular risk in HCM.

\section{Methods}

Cine CMR and LGE imaging were performed on HCM patients with massive LV hypertrophy and compared with those with a maximal LV wall thickness $<30 \mathrm{~mm}$.

\section{Results}

Among 902 consecutive HCM patients, 40 (4.4\%) had a maximal LV wall thickness of $\geq 30 \mathrm{~mm}$ (mean thickness $33.7 \pm 4.2 \mathrm{~mm}$, range $30-50 \mathrm{~mm}, 23 \%$ females) with a mean age of $37 \pm 18$ years old, including 11 patients $(28 \%) \geq 50$ years of age. When compared to those with a maximal wall thickness less than $30 \mathrm{~mm}$, these patients were significantly younger (mean age $37 \pm 18$ vs $47 \pm$ $18, \mathrm{p}<0.001)$ and had a similar proportion of males (77.5\% versus $66.8 \%, \mathrm{p}=0.16$ ). Mean left ventricular mass was significantly higher $(317 \pm 142$ versus $163 \pm 62$ grams, $\mathrm{p}<0.001)$. They also had significantly higher LV end diastolic volume (LVEDV) $(169.6 \pm 58.5$ versus $153.0 \pm 42.1 \mathrm{~mL}, \mathrm{p}<0.01)$ and $\mathrm{LV}$ end systolic volume

${ }^{1}$ cardiology, BIDMC, Boston, MA, USA

Full list of author information is available at the end of the article
(LVESV) $(63.0 \pm 40.8$ versus $49.9 \pm 23.1 \mathrm{ml}, \mathrm{p}=0.001)$ They had similar LV ejection fraction $(64.8 \pm 10.7 \%$ versus $67.6 \pm 9.6 \%, \mathrm{p}=0.21)$, LVEDD $(51.7 \pm 9.2 \mathrm{~mm}$ versus $53.1 \pm 6.8 \mathrm{~mm}, \mathrm{p}=0.21)$, and stroke volume $(106.6 \pm 27.5$ $\mathrm{ml}$ versus $103.1 \pm 30.8 \mathrm{ml}, \mathrm{p}=0.48$ ).

LGE was identified in $95 \%$ of HCM patients with massive $\mathrm{LVH}$, occupying an average of $19.6 \mathrm{~g} \pm 19.8 \mathrm{~g}$ (or 6.1 $\pm 4.7 \%$ ) of LV myocardial mass. $18 \%$ had LGE occupying $>10 \%$ of the LV. In comparison, only $38 \%$ of HCM patients without massive LVH had LGE ( $\mathrm{p}<0.001)$, occupying an average of only $13.6 \pm 17.0 \mathrm{~g}$ (or $7.8 \pm 9.6 \%$ ) of LV myocardial mass $(\mathrm{p}=0.05)$.

Univariate associates of massive hypertrophy include young age ( $\mathrm{OR}=1.37 /$ decade decrease in age, $\mathrm{p}<0.001)$, presence of LGE (OR 25.6, $\mathrm{p}<0.001$ ), amount of LGE present $(O R=1.31$ per $10 \mathrm{~g}$ increase, $\mathrm{p}<0.001)$, presence of LV dysfunction (defined as $L V E F<50 \%$ ) (OR 3.28, $\mathrm{p}=0.01)$, LVEDV (OR $=1.08$ per $10 \mathrm{ml}$ increase in LVEDV, $\mathrm{p}=0.018)$, and LVESV $(\mathrm{OR}=1.16$ per $10 \mathrm{ml}$ increase in LVESV, $\mathrm{p}=0.001$ ). On multivariate regression analysis, presence of LGE (adjusted OR 21.3, $\mathrm{p}<0.0001$ ) and young age (adjusted $\mathrm{OR}=1.43 /$ decade decrease in age, $\mathrm{p}=0.0014$ ) remained significant after controlling for other factors.

When comparing patients older and young than 30 years old with massive hypertrophy, there were no significant differences in LV mass, stroke volume or quantity of LGE $(p>0.10)$. Older patients had a smaller cavity size $(\mathrm{p}=0.04)$ and better cardiac function $(\mathrm{LVEF}=67.7$ $\pm 9.8 \%$ versus $60.8 \pm 10.9 \%, \mathrm{p}=0.046$ ).

(C) 2012 Chan et al; licensee BioMed Central Ltd. This is an open access article distributed under the terms of the Creative Commons 


\section{Conclusions}

Almost all HCM patients with massive LV hypertrophy demonstrate LGE. These observations may complement findings demonstrating an increased risk with LGE. Patients with massive LVH surviving to older age had better cardiac function and less dilation.

\section{Funding}

n/a.

\section{Author details}

${ }^{1}$ cardiology, BIDMC, Boston, MA, USA. ${ }^{2}$ Tufts Medical Center, Boston, MA, USA. ${ }^{3}$ Minneapolis Heart Institute Foundation, Minneapolis, MN, USA.

Published: 1 February 2012

doi:10.1186/1532-429X-14-S1-099

Cite this article as: Chan et al:: Characterization of patients with massive hypertrophic cardiomyopathy using contrast-enhanced magnetic resonance imaging: does contrast provide additional information? Journal of Cardiovascular Magnetic Resonance 2012 14(Suppl 1):099.

Submit your next manuscript to BioMed Central and take full advantage of:

- Convenient online submission

- Thorough peer review

- No space constraints or color figure charges

- Immediate publication on acceptance

- Inclusion in PubMed, CAS, Scopus and Google Scholar

- Research which is freely available for redistribution

Submit your manuscript at www.biomedcentral.com/submit
C Biomed Central 